\title{
The Demography, Clinical Characteristics, and White Blood Analysis of Leprosy Reactions in Multibacillary Leprosy: A Retrospective Study
}

\author{
Natalia Tanojo $^{1}$, Damayanti ${ }^{1}$, Budi Utomo ${ }^{2}$, Evy Ervianti ${ }^{1}$, Dwi Murtiastutik ${ }^{1}$, Cita Rosita \\ Sigit Prakoeswa ${ }^{1}$, M. Yulianto Listiawan 1 ib \\ ${ }^{1}$ Departement of Dermatology and Venereology, Universitas Airlangga/Dr. Soetomo General \\ Academic Hospital, Universitas Airlangga, Surabaya \\ ${ }^{2}$ Departement of Public Health - Preventive Medicine, Medicine Faculty of Airlangga University
}

\begin{abstract}
Background: Leprosy is a neglected tropical disease caused by chronic granulomatous infection of Mycobacterium leprae. Indonesia ranks third in new case findings, with $84 \%$ of the case being multibacillary (MB) leprosy. MB leprosy cases have a higher risk of leprosy reactions and physical disabilities that decrease quality of life. Purpose: To determine the demographic, clinical characteristics, and white blood analysis of newly diagnosed MB leprosy patients, especially concerning leprosy reactions. Methods: This is a descriptive retrospective study with a cross-sectional design that describe the following data: domicile, gender, age, treatment status, disabilities, body mass index (BMI); bacterial index (BI), morphological index (MI), white blood cell (WBC) and differential counts, and thrombocyte count. Result: This study included 176 adult MB cases, predominantly male aged 20-39 years old with average BMI, lived in Surabaya with negative history of multi-drug therapy, disability, BI, nor MI. The grade 2 disability (G2D) percentage in this study setting than in Indonesia (10.7\% vs. $6.43 \%)$. The WBCs, especially neutrophil count, was higher in T2R group. Monocyte and lymphocyte counts were relatively similar. There was an increase in thrombocyte count in leprosy reaction groups. Conclusion: MB leprosy in the endemic area, which is more commonly found in productive-aged male, displayed higher G2D than global Indonesia population. Thus denotes the importance of active case findings. The difference in blood analysis characteristics between MB leprosy with and without reactions may serve as the foundation for future study.
\end{abstract}

Keywords: tropical disease, leprosy, multibacillary, leprosy reactions, reversal reaction, erythema nodosum leprosum.

Correspondence: M. Yulianto Listiawan, Department of Dermatology and Venerology Faculty of Medicine, Universitas Airlangga / Dr. Soetomo General Academic Teaching Hospital, Surabaya, Jl. Mayjen Prof. Dr. Moestopo No. 6-8 Surabaya 60131, Indonesia. Phone: 0811323730, e-mail: yuliantowawan@yahoo.com.

Article info | Submited: 16-8-2021, Accepted: 6-10-2021, Published: 30-11-2021

\section{BACKGROUND}

Leprosy is a neglected tropical disease that affects more than 120 countries, with more than 200,000 new cases reported annually. Indonesia is amongst the top three countries with the highest number of new cases after India and Brazil. ${ }^{1}$ Despite the decrease in the number of leprosy case in the world, the number of new leprosy cases in Indonesia increase from 15.910 in 2017 to 17.439 in $2019 .{ }^{1}$ Approximately $21.19 \%$ of these new leprosy cases were found in East Java province of Indonesia. ${ }^{2}$ With Surabaya being the capital of the East Java province and Dr. Soetomo General Academic Teaching Hospital as the tertiary referral hospital, further study regarding the demographic of the newly diagnosed patient in the leprosy division of the hospital may give better understanding regarding the current state of leprosy in the most endemic area of leprosy in Indonesia.

Approximately $84 \%$ of the reported new leprosy case can be classified as multibacillary (MB) leprosy., ${ }^{1,3}$ MB leprosy is a form of chronic granulomatous infection of the skin and peripheral nerve caused by Mycobacterium leprae with a higher number of circulating pathogens and often more detrimental complications than its milder counterpart, paucibacillary (PB) leprosy. ${ }^{4} \mathrm{MB}$ complications are initiated by leprosy reactions, immunological responses to $M$. leprae antigen with two distinct types: Type 1 reaction (T1R), also known as reversal reactions, and Type 2 reactions (T2R), also known as erythema nodosum leprosum. ${ }^{4,5}$ Peripheral nerve damage found in MB leprosy, especially in relation to leprosy reactions, often leads to physical disability and deformity; thus, highlighting the importance of a deeper understanding of MB leprosy. ${ }^{6}$ However, there is very little knowledge regarding the clinical characteristics, including the gender, age, treatment status, disability, nutritional status, bacterial index (BI), and morphological index (MI) of these patients.

Various types of white blood cell play major role in the pathogenesis of leprosy reactions, arising more commonly from MB leprosy. ${ }^{5,7}$ A study by Gomes et 
$a l .{ }^{4}$ indicated that simple white blood analysis can help to determine the number of neutrophil and lymphocyte that may be used as a ratio to support the diagnosis of T2R. This study indicated that understanding changes in the white blood cells may help us to better understanding leprosy reactions in MB leprosy. Thus, this retrospective study aimed to determine the demographic, clinical characteristics, and white blood analysis of newly diagnosed MB leprosy, especially concerning leprosy reactions with the aim to support the clinical judgment for diagnosis and possible insight into future diagnosis and treatment evaluation.

\section{METHODS}

This is a descriptive retrospective study with a cross-sectional design that aims to evaluate the demographic and clinical data of new adult $\mathrm{MB}$ patients aged 20 years or more in the leprosy division of Dr. Soetomo General Academic Teaching Hospital in 2018-2020. Adult subjects mean those aged 20 years old and above. The descriptive data included the demographic distribution and clinical characteristics of gender, age, treatment status, body mass index (BMI), bacterial index (BI), and morphological index (MI). A white blood cell (WBC) count and differential were tested on the day of diagnosis. This research has been reviewed by the Ethics Committee at dr. Soetomo General Academic Hospital Surabaya with a reference number of $0459 / \mathrm{LOE} / 301.4 .2 / \mathrm{V} / 2021$.

\section{RESULT}

A total of 280 new patients visited Leprosy Division in January 2018-December 2020 with MB leprosy patients, only 176 patients aged 20 years or more and had performed laboratory examinations on the day of diagnosis.

Table 1. Demographic distribution of MB leprosy cases in dr. Soetomo General Academic Teaching Hospital in 2018-2020

\begin{tabular}{|c|c|c|c|c|c|c|c|c|}
\hline \multirow[b]{2}{*}{ City } & \multicolumn{2}{|c|}{2018} & \multicolumn{2}{|c|}{2019} & \multicolumn{2}{|c|}{2020} & \multicolumn{2}{|c|}{ Total } \\
\hline & $\mathrm{n}$ & $(\%)$ & $\mathrm{n}$ & $(\%)$ & $\mathrm{n}$ & $(\%)$ & $\mathrm{n}$ & $(\%)$ \\
\hline Ambon & 0 & (0) & 1 & $(0.56)$ & 0 & $(0)$ & 1 & $(0.56)$ \\
\hline Blora & 0 & $(0)$ & 0 & $(0)$ & 1 & $(0.56)$ & 1 & $(0.56)$ \\
\hline Gresik & 5 & $(2.84)$ & 1 & $(0.56)$ & 5 & (2.84) & 11 & $(6.25)$ \\
\hline Jombang & 0 & $(0)$ & 2 & (1.13) & 0 & $(0)$ & 2 & (1.13) \\
\hline Kediri & 1 & $(0.56)$ & 0 & $(0)$ & 0 & $(0)$ & 1 & $(0.56)$ \\
\hline Kupang & 1 & $(0.56)$ & 1 & $(0.56)$ & 0 & $(0)$ & 2 & (1.13) \\
\hline Lamongan & 3 & $(1.70)$ & 3 & $(1.70)$ & 2 & (1.13) & 8 & (4.54) \\
\hline Madiun & 0 & $(0)$ & 1 & $(0.56)$ & 0 & $(0)$ & 1 & $(0.56)$ \\
\hline Madura & 15 & $(8.52)$ & 7 & (3.97) & 1 & $(0.56)$ & 23 & (13.0) \\
\hline Probolinggo & 1 & $(0.56)$ & 2 & (1.13) & 1 & $(0.56)$ & 4 & $(2.27)$ \\
\hline Sidoarjo & 7 & (3.97) & 6 & $(3.40)$ & 2 & (1.13) & 15 & $(8.52)$ \\
\hline Surabaya & 49 & $(27.8)$ & 32 & $(18.1)$ & 22 & $(12.5)$ & 103 & $(58.5)$ \\
\hline Tuban & 1 & $(0.56)$ & 1 & $(0.56)$ & 0 & $(0)$ & 2 & (1.13) \\
\hline Tulung Agung & 1 & $(0.56)$ & 0 & $(0)$ & 0 & (0) & 1 & $(0.56)$ \\
\hline Total (\%) & 84 & $(47.7)$ & 57 & $(32.3)$ & 34 & (19.3) & 175 & $(99.4)$ \\
\hline
\end{tabular}

Table 1 indicated that MB cases decreased from 84 in 2018 to 57 in 2019 and 34 in 2020. Patients came from 14 different cities of East Java, with most living in Surabaya $(58.5 \%)$, Madura $(13 \%)$, and Sidoarjo $(8.52 \%)$. There was 1 subject with no domicile data. Table 2 shows the clinical characteristics of MB leprosy patients based on the leprosy reaction status. MB patients with no leprosy reaction were predominantly male (71\%) aged 20-39 years old $(54.3 \%)$ with no history of leprosy treatment $(86.9 \%)$. Grade 2 disability (G2D) was discovered in $12.3 \%$ of MB cases with no leprosy reactions. The subjects had BMI of 18.5-22.9 (47.8\%) with negative BI (50\%) and MI (56.5\%). Approximately 17 subjects presented with
T1R. The subjects were predominantly male $(76,4 \%)$, aged 20-39 years old $(52,9 \%)$, with no history of previous MDT treatment (64.7\%). Grade 2 disability (G2D) was observed in $5.88 \%$ of MB cases with T1R. The T1R was more common in patients with a BMI of 18.5-22.9 (41.1\%), negative BI (58.8\%), and MI $(64.7 \%)$. The 21 subjects with T2R were predominantly males (71.4\%) aged 20-39 years old. $\mathrm{T} 2 \mathrm{R}$ was more common in subjects with no treatment history $(47.6 \%)$ or subjects released from treatment or control $(33.3 \%)$. The G2D rate was just $4.76 \%$. The majority of T2R cases were observed in subjects with average BMI (57.1\%) who had a BI of 1-2 (76.1\%) but a negative MI (61.9\%). 
Table 2. Clinical characteristics of MB leprosy cases in dr. Soetomo General Academic Teaching Hospital based on leprosy reaction status

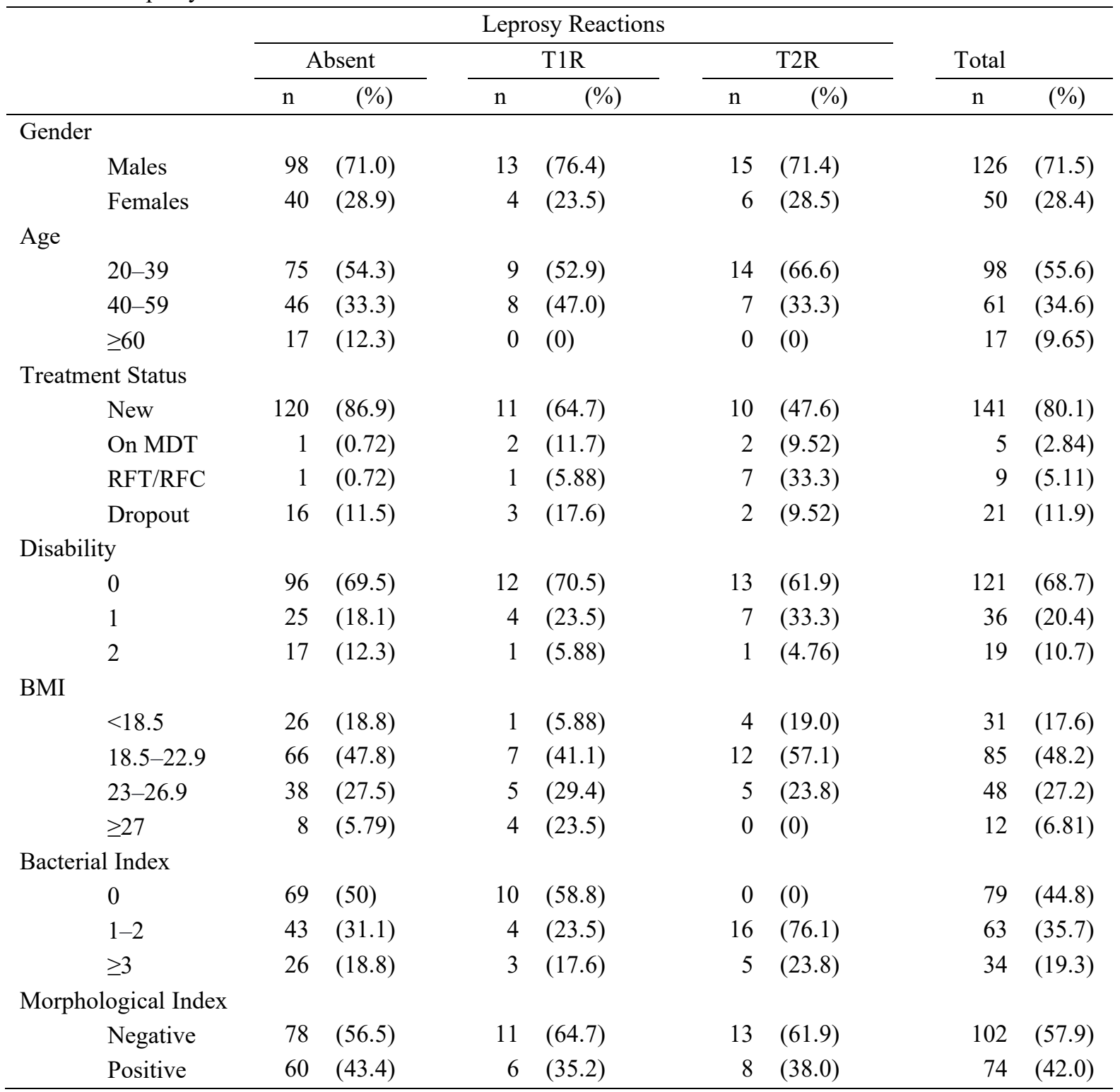

T1R=Type 1 Reaction; T2R=Type 2 Reaction, MDT=multidrug therapy, RFT=release from treatment, $\mathrm{RFC}=$ release from control, $\mathrm{BMI}=$ body mass index

Neutrophils count of MB with no reaction had a median of 4,840 (2,010-19,540), while MB with T1R had a median of 5,260 $(3,036-16,800)$ and MB with T2R had a median of 13,120 (3,520-26,840). Lymphocyte count of MB with no reaction had a mean of 1,776.54 ( \pm 629.29$)$, while MB with T1R had a mean of $1,400.35( \pm 509.19)$ and MB with T2R had a mean of $1.546,19$ ( \pm 665.27$)$. Monocyte count of MB with no reaction had a median of $570(200-1,390)$, while MB with T1R had a median of $690(390-1,450)$ and MB with T2R had a median of $790(210-1,910)$.
Figure 1 displayed a WBC count of MB with no reaction with a median of 7,435 $(4,380-21,980)$, while MB with T1R had a median of 7,140 $(4,600-19,730)$ and MB with T2R had a median of $14,910(4,160-$ $30,330)$.

In Figure 2, the thrombocyte count of MB with no reaction had a median of 293,000 (116,000-721,000), while MB with T1R had a median of 340,000 $(191,000-646,000)$ and MB with T2R had a median of $361,000(229,000-909,000)$. 


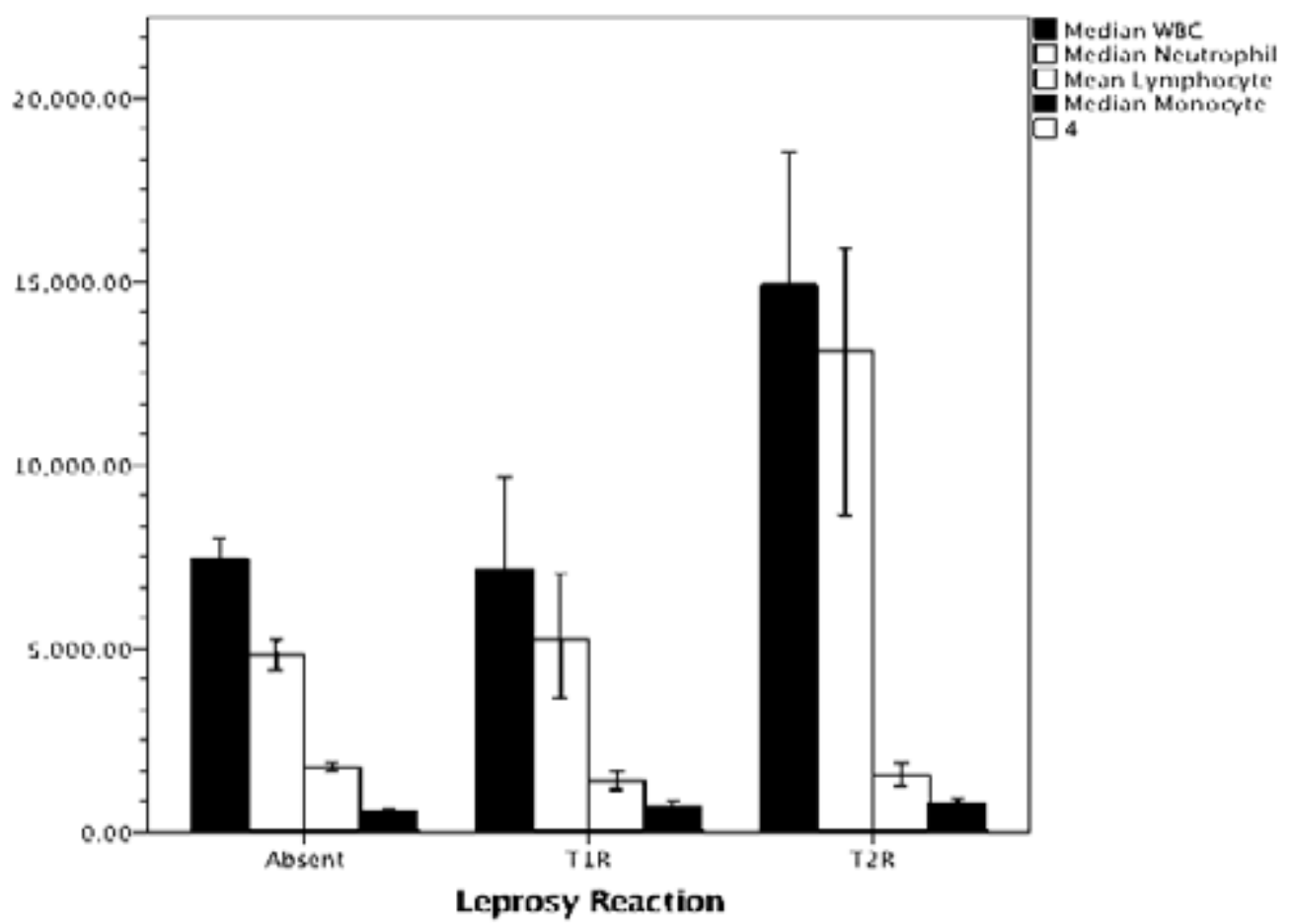

Error Bars: $95 \%$ CI

Figure 1 White blood cell count and differential of multibacillary leprosy patients, based on the leprosy reactions.

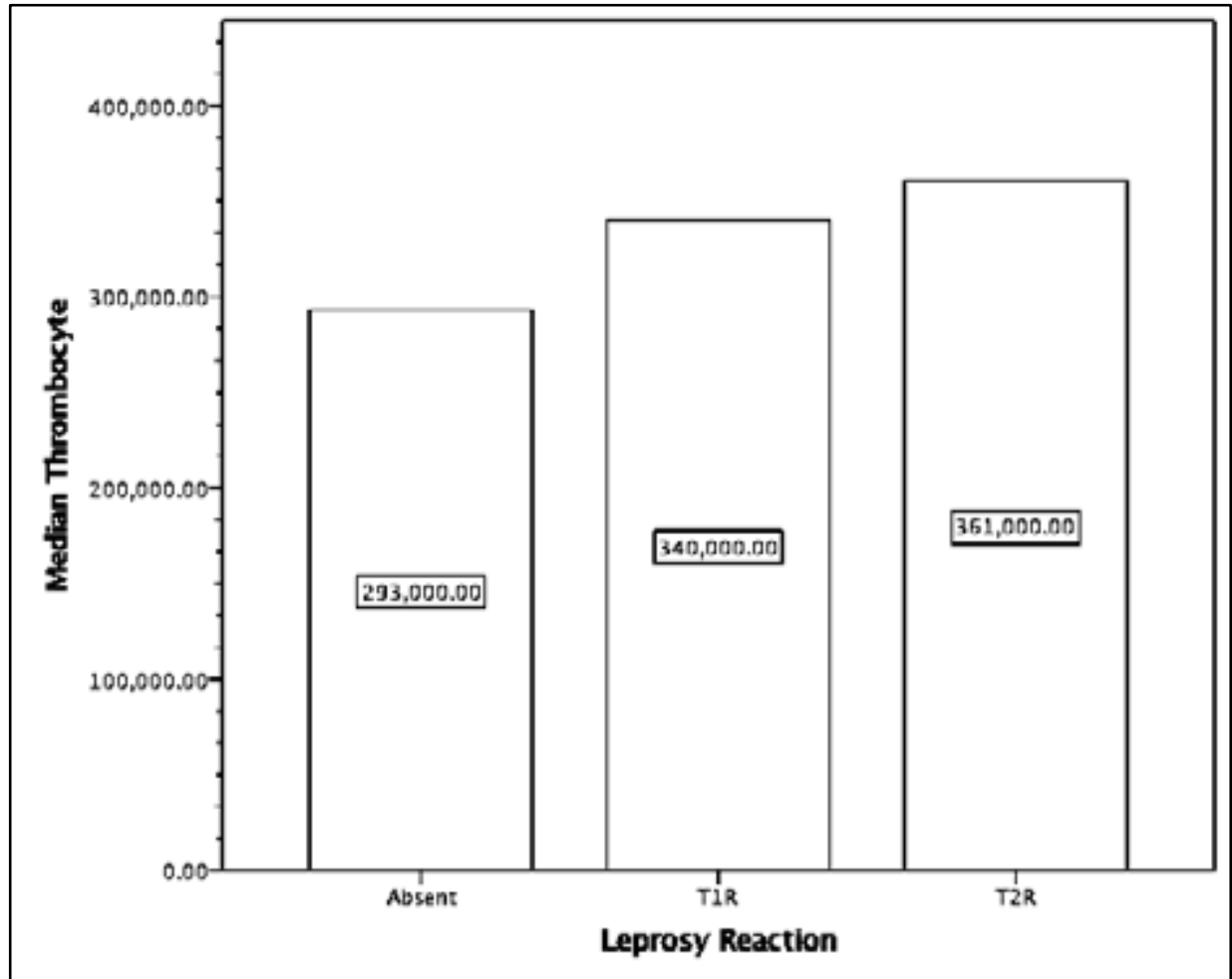

Figure 2 Thrombocyte count of multibacillary leprosy patients, based on the leprosy reactions.

\section{DISCUSSION}

This study described a decreasing number of new leprosy patients visiting the leprosy division of $\mathrm{dr}$. Soetomo General Academic Teaching Hospital in Surabaya, East Java. A four-year study from the same hospital reported 594 leprosy patients in 2010-2013. ${ }^{8}$
The total number of leprosy patients reduced from 385 patients in 3 years (2015-2017) to 280 patients in 3 years (2018-2020)..$^{9,10}$ This was consistent with the decreasing trend in the number of leprosy cases reported by the World Health Organization (WHO). ${ }^{1}$ All subjects resided in cities of East Java, mainly from 
Surabaya (58.5\%), which is the location of the hospital, Madura (13\%), which is an island that has direct access to the city, and Sidoarjo (8.52\%), which is located right next to Surabaya. East Java is part of Indonesia province that had the highest rate of new case findings of leprosy (21.19\%). ${ }^{2,11}$ Amongst all cities in East Java, the cities of Madura Island were at higher risk of leprosy. ${ }^{11}$ The number of the patient coming from Madura was lower than Surabaya, perhaps related to the fact that this study was limited to new patients visiting dr. Soetomo General Teaching Academic Hospital. Distance could be an obstacle to getting treatment for leprosy patients outside Surabaya.

Leprosy was frequently reported higher in adult males aged 20 and above, while the possibility of leprosy reactions heightened before the age of 40 with no gender preference. ${ }^{12,13}$ Slight male predomination might be related to psychosocial and economic problems faced by adult males in the productive age group (20-40 years) rather than biological differences between males and females. Males as the backbone of the family were expected to be more active in looking for treatment with a possible explanation that women of the rural area had lower access to health services. ${ }^{14,15}$ Biological differences between males and females may affect the disease in younger age group or adolescent period, hypothetically due to hormone levels during reproductive age. ${ }^{15}$

Approximately $80.1 \%$ of newly diagnosed MB leprosy patients in this study had no history of MDT treatment. A similar trend was observed in both patients without leprosy reaction and those with T1R. However, new MB leprosy patients with T2R seemed to rise with $\mathrm{RFT} / \mathrm{RFC}$ group. T2R is mediated by immune complexes involving $\mathrm{B}$ lymphocytes due to an increase in the number of post-treatment bacterial antigens and then manifests clinically as the Arthus phenomenon. ${ }^{16}$ Patients receiving Multi-Drug Therapy (MDT) or Released from Treatment (RFT) are both at higher risk of developing T2R, especially on the first six months of therapy or 2-3 years after 12 months of MDT. ${ }^{17}$ This explains the increase of $\mathrm{T} 2 \mathrm{R}$ in the RFT/RFC group. This study limited its data to initial diagnosis and thus incapable of showing the true onset of T2R in MB patients during MDT treatment.

Physical impairments are secondary to nerve damage and are often found in poorly managed leprosy cases and leprosy reactions. ${ }^{3}$ The impairments are the root of the well-known social stigma in the literature of ancient civilization that continued till now and the limitation to daily activities. The prevention of disability, especially G2D, has become one of the current goals of the Global Leprosy Strategy 20212030 by WHO. There were 1,118 cases $(6.57 \%)$ and
1,121 cases $(6.43 \%)$ of G2D in 2018 and 2019, respectively, amongst the leprosy cases in Indonesia. ${ }^{1}$ The percentage G2D of MB patients in this study was slightly higher than in the Indonesian population. A study by de Paula et al. ${ }^{6}$ indicated that MB patients were 4-fold more likely to have physical impairment (pooled OR, 4.32; 95\% CI, 3.37-5.53; I2, 88.9\%, P < 0.001). The G2D found in T1R was $5.88 \%$, while T2R was $4.76 \%$. The percentage number was less than the non-reaction group (12.3\%). Leprosy reactions may damage peripheral nerves, resulting in impaired organ function during any course of the disease, regardless of treatment. ${ }^{3,6}$ A systematic review found that disabilities were more likely to occur in leprosy reactions (pooled OR, 2.43; 95\% CI, 1.35-4.36; I2, 92.1\%; P < 0.001). ${ }^{6}$ The higher percentage of G2D found in this study may be related to the fact that our study focused only on MB patients visiting the hospital. Leprosy reactions seem to have a lesser G2D percentage than the non-reaction group at the initial diagnosis. A further study with a better definition of T1R and T2R and a larger scale may give a better picture of the incidence of G2D in leprosy reactions.

The majority of MB leprosy cases were found in patients with negative BI (44.8\%) and MI (57.9\%). Both BI and MI have routine examinations that help to diagnose and monitor treatment in a leprosy patient. Higher BI is generally found in MB leprosy, especially the lepromatous and borderline lepromatous types in the Ridley-Jopling classification. ${ }^{12}$ BI shows the density of M. leprae bacilli, which includes live and dead bacteria, which describes the antigen load. ${ }^{12}$ Leprosy cases of the borderline group in the RidleyJopling classification (somewhere between PB and MB leprosy) are associated with BI of 1-4 and more likely to develop T1R. ${ }^{12}$ A high antigen load will interact with antibodies to produce immune complexes that can trigger T2R. A BI of $>4+$ is one of the risk factors of $\mathrm{T} 2 \mathrm{R} .{ }^{5}$ Morphological index is the ratio between live or intact germs to the whole BTA. Research from Manandhar, et $a l .{ }^{18}$ did not find a significant relationship between changes in $\mathrm{MI}$ and the incidence of leprosy reactions. It was hypothesized that the fraction of dead germs might trigger leprosy reaction, proposing that the incidence of $\mathrm{T} 2 \mathrm{R}$ would be more common in a MI of less than $5 \%$ or with an increase in bacterial death.

The white blood cells (WBCs) play an important role in the defense against pathogens. Depending on the invading organisms, a different group of WBCs will become more active. One of the most renowned WBCs against $\mathrm{M}$. leprae invasion was macrophage or tissue monocyte. ${ }^{19}$ Macrophage detects and activates immune response during pathogen invasion, then presents the 
antigen to lymphocytes through major histocompatibility complex. ${ }^{20}$ Lymphocytes work in humoral immunity against circulating pathogens. Although the number of lymphocytes during T1R increased in the in vitro study, a clinical study found that the difference in lymphocyte count between different leprosy clinical manifestations might not be of importance. ${ }^{4,21}$ Neutrophils constitute most of WBCs and are essential in pathogen elimination through various intracellular and extracellular mechanisms. A study found that the neutrophil count increased in $\mathrm{MB}$ with a $\mathrm{BI}$ of $\geq 3$ and leprosy reactions. ${ }^{4}$ Thrombocytes form microthrombus and trap pathogens, thus preventing dissemination. There is an increase in thrombocytes activities in $\mathrm{T} 2 \mathrm{R}$ proven by prolonged partial thromboplastin time. ${ }^{22}$ This study found that the median of WBC and neutrophil were visibly higher in the $\mathrm{T} 2 \mathrm{R}$ group than the non-reaction and T1R group. Thrombocytes were slightly higher in both leprosy reactions, while monocytes and lymphocytes had only slight differences.

The distribution and clinical characteristics of MB leprosy in the hospital setting displayed in this study may help clinicians to understand the characteristics of MB leprosy in the third country with the most number of new leprosy cases in the world. MB leprosy in this study was more commonly found in productive-aged male and displayed higher G2D than global Indonesia population. The higher G2D percentage in previously untreated MB patients suggested that active case finding would be essential in disability prevention in order achieve the WHO goals. This study also found out that the total WBC count and the differential count between the leprosy reactions and the non-reaction group displayed different characteristics. The difference may serve as potential future leprosy studies, such as finding biomarkers in acute phase reactions to diagnose and evaluate disease prognosis.

\section{REFERENCES}

1. World Helath Organization. Global leprosy (Hansen disease) update, 2019: time to step up prevention initiatives. Weekly Epidemiological Record 2020:36(95):417-40.

2. Dinas Kesehatan Provinsi Jawa Timur. Pengendalian penyakit, profil kesehatan Jawa Timur 2019. Surabaya: Dinkes Provinsi Jawa Timur. 2020.

3. van Brakel WH, Sihombing B, Djarir H, Beise K, Kusumawardhani L, Yulihane R, et al. Disability in people affected by leprosy: the role of impairment, activity, social participation, stigma and discrimination. Glob Health Action 2012; 1-
11.

4. Gomes L, Morato-Conceição Y, Gambati A, Maciel-Pereira C, Fontes C. Diagnostic value of neutrophil-to-lymphocyte ratio in patients with leprosy reactions. Heliyon. 2020;6(2):1-6.

5. Kar HK, Chauhan A. Leprosy reactions: pathogenesis and clinical features. In: Kumar B, Kar HK, editors. IAL Textbook of leprosy. New Delhi: Jaypee Brothers Medical Publishers; 2017. p. 416-40.

6. de Paula HL, de Souza CDF, Silva SR, MartinsFilho PRS, Barreto JG, Gurgel RQ, et al. Risk factors for physical disability in patients with leprosy: a systematic review and meta-analysis. JAMA Dermatology 2019; 155(10): 1120-8.

7. Polycarpou A, Walker SL, Lockwood DNJ. A Systematic Review of Immunological Studies of Erythema Nodosum Leprosum. Front Immunol 2017; 8: 233:1-41.

8. Pratamasari MA, Listiawan MY. Retrospective study: type I leprosy reaction. Berkala Ilmu Kesahatan Kulit dan Kelamin 2015; 27(2): 13743.

9. Fransisca C, Zulkarnain I, Ervianti E, Damayanti, Sari M, Budiono, et al. A retrospective study: epidemiology, onset, and duration of erythema nodosum leprosum in Surabaya, Indonesia. BIKKK 2021; 33(1): 8-12.

10. Listiyawati IT, Sawitri S, Agusni I, Prakoeswa CRS. Terapi kortikosteroid oral pada pasien baru kusta dengan reaksi tipe 2. BIKKK 2015; 27(1): 48-54.

11. Kementrian Kesehatan RI. Pusat Data dan Informasi Kementrian Kesehatan. Infodatin. Hapuskan stigma dan diskriminasi terhadap kusta. Jakarta: Kementrian Kesehatan Republik Indonesia. 2018.

12. Salgado CG, de Brito AC, Salgado UI, Spencer SJ. Leprosy. In: Kang S, Amagai M, Bruckner AL, Enk AH, Margolis DJ, Mcmichael AJ, et al., editors. Fitzpatrick's Dermatology in General Medicine. New York: McGrawHill; 2019. p. 2892-925.

13. Nobre ML, Illarramendi X, Dupnik KM, Hacker $\mathrm{M}$ de A, Nery JA da C, Jerônimo SMB, et al. Multibacillary leprosy by population groups in Brazil: Lessons from an observational study. PLoS Negl Trop Dis 2017; 11(2): e0005364.

14. Suchonwanit P, Triamchaisri S, Wittayakornrerk $\mathrm{S}$, Rattanakaemakorn P. Leprosy reaction in Thai population: a 20-year retrospective study. Dermatol Res Pract 2015; 253154.

15. Liu Y-Y, Yu M-W, Ning Y, Wang H. A study on gender differences in newly detected leprosy 
cases in Sichuan, China, 2000-2015. Int J Dermatol 2018; 57(12): 1492-9.

16. Porichha D, Natrajan M. Pathological aspects of leprosy. In: Kumar B, Kar HK, editors. IAL Textbook of leprosy. New Delhi: Jaypee Brothers Medical Publishers; 2017. p. 132-52.

17. Balagon MVF, Gelber RH, Abalos RM, Cellona $\mathrm{R}$ V. Reactions following completion of 1 and 2 year multidrug therapy (MDT). Am J Trop Med Hyg 2010; 83(3): 637-44.

18. Manandhar R, LeMaster JW, Roche PW. Risk factors for erythema nodosum leprosum. Int $\mathrm{J}$ Lepr Other Mycobact Dis 1999; 67(3): 270-8.

19. Shibuya M, Bergheme G, Passos S, Queiroz I, Rêgo J, Carvalho LP, et al. Evaluation of monocyte subsets and markers of activation in leprosy reactions. Microbes Infect 2019; 21(2): 94-8.

20. Delves PJ, Martin SJ, Burton DR, Roitt IM. Roitt's essential immunology. 13th ed. Chichester: John Wiley \& Sons, Ltd; 2017.

21. Yusuf I, Agusni I. Lymphocyte response to mycobacterium leprae antigens in reversal reaction state of leprosy. Indones J Trop Infect Dis 2015; 5(4): 96.

22. Gupta M, Bhargava M, Kumar S, Mittal MM. Platelet function in leprosy. Int $\mathrm{J}$ Lepr other Mycobact Dis Off organ Int Lepr Assoc 1975; 43(4): 327-32. 